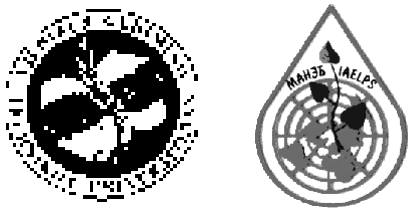

\title{
STABILITY AND INSTABILITY OF AN OUTDOOR ILLUMINATION INSTALLATION
}

\author{
Klaus-Dieter Fröhner, Ze Li \\ Institute of Ergonomics, Technical University of Hamburg-Harburg, \\ Eissendorfer Strasse 40, 21073 Hamburg, Germany.E-mail: Arbeitswissenschaft@TUHH.de
}

Received 14 Oct 2002; accepted 14 Jan 2003

\begin{abstract}
Stability and instability are very important for the layout of real world processes concerning safety and health esp. when planned by scientists. The long-term investigation of stability was carried out for the last ten years on the basis of the installation and the evaluation of an ergonomically designed outdoor illumination. In the depicted dynamic situation the lighting design influences directly visual discomfort and human performance and in the end stability and instability. The improvement of the adaptation of luminance and its influence on the visual tasks after the rearrangement are presented and discussed. The effective factors on the visual capability and performance of workers, work efficiency and potential accidents in the night shift, and furthermore the accelerators and barriers for the stability of the project are analysed and discussed.
\end{abstract}

Keywords: stability, illumination, luminance, visual discomfort, human performance, railroad yard

\section{Introduction}

The stability and the instability of installations are a major concern when realizing projects. This is especially influenced by to-day's economic development with many reasons for intervention and change that can override layouts. On the basis of an ergonomic design, construction and evaluation of a project, it was seen as important to undertake a generalized survey in order to discuss and explain the effective factors for the longterm stability and instability of a realized project. Carried out for the last ten years, a longitudinal study was used. The project procedure is shown in Fig 1.

The intentions of this project came from the complaints of the workers because of bad-quality lighting situation, insufficient light for the performance of tasks and the fears of increased accidents from the management. In order to determine the best form of lighting for the task and human performance, an ergonomic analysis of the illumination conditions of the Central Railroad Yard "Hamburg South" was carried out in 1991 in the 1st phase of this project. On the basis of the analysis, a pilot lighting system was designed, installed and evaluated at first. The whole lighting system was rearranged and constructed as it was shown in [1]. Five years later in the 2 nd phase the subjective judgments and objective measurements were carried out showing the high perceived and stable improve- ment with some lighting standards not realized and others overperformed, to install a person-oriented lay-out on the one-hand side and reduce the use of lighting and thereby save energy on the other-hand side, as shown in [2]. In the 3rd phase about five years later, the stability and the instability of the outdoor illumination were analysed via a generalized survey.

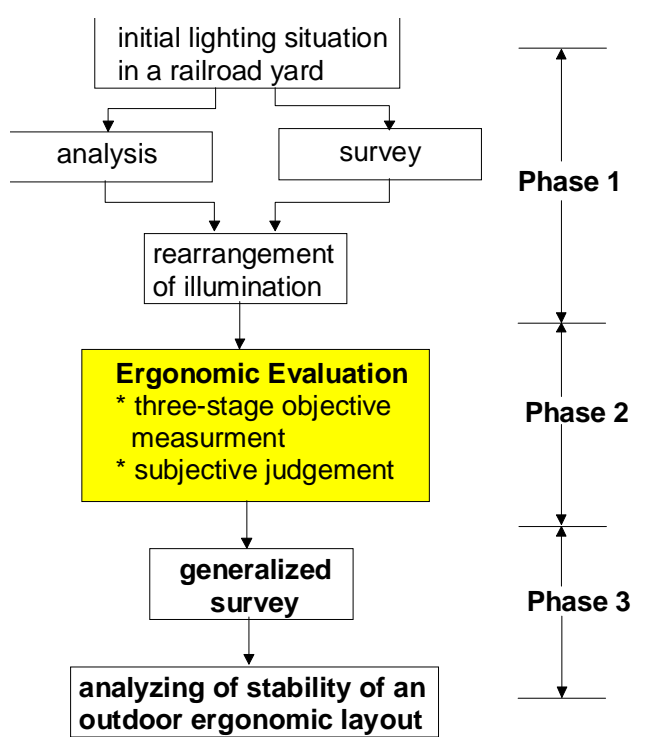

Fig 1. Project procedure 
The aim of this paper is to explain the relationship between visual indicators (visual discomfort and human performance) and the state of stability in lighting maintenance, and furthermore to explain the reasons and present the results about the acknowledgements concerning the impact on the stability and the instability of the ergonomically designed layout and try to generalize this.

\section{Analysis of visual discomfort, stability and human performance}

The initial situation of the lighting system before intervention could be characterized by low illuminance level, low uniformity concerning illuminance level, low contrast and strong glare. And what seems to be contradictory at a first glance, although the visibility was low, a low maintenance level for the lighting system was realized in face of a high throughput of wagons at that time.

From a scientific view it was quite obvious that the quality of lighting affects directly the visual discomfort and furthermore the human performance and motivation. It was seen decisive for how exact and quick the form of objects, details and colours are going to be recognized for the tasks in a railroad yard. Poor lighting can lead to strain, visual fertigue and disturbance of the circadian system of workers. Fig 2 shows relations between visual discomfort, human performance and stability of illumination that very assumed and present the important factors in the approach.

Inadequate visual conditions, such as low illuminance level, low uniformity and dark adaptation, demand continuous adjustments of the human visual system and cause indirectly visual discomfort. Visual discomfort is actually changed by individual differences. The situation of illumination stability depends on maintenance level and economic and working environment. Both parameters "visual discomfort" and "stability of illumina-

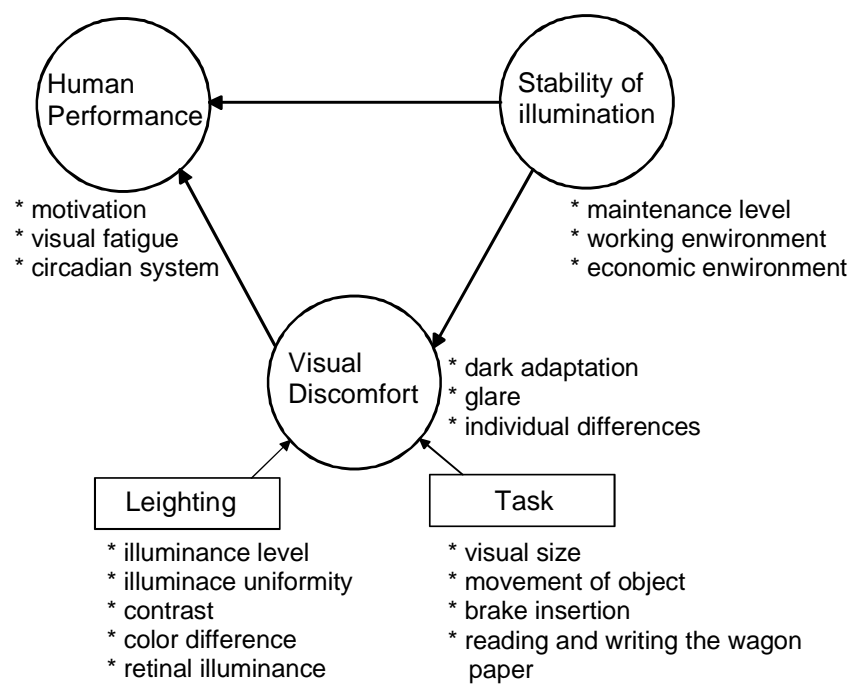

Fig 2. Relations between visual discomfort, human performance and stability of illumination tion" in Fig 2 affect human performance, work quality and personal health care.

In the first phase of this project, it is found that the uniformity of illuminance and luminance plays a very important role for the retinal image quality, cognitive and motor performance. When the visual system is not completely adapted to the prevailing retinal illumination, its capabilities are limited. This state of changing adaptation - transient adaptation - can be significant where sudden changes from high to low retinal illumination occur. Visually, dark adaptation is experienced as temporary blindness that occurs when someone goes rapidly from photopic to scotopic levels of illumination. The state of the visual system changes at adaptation luminance from higher than approximately $3 \mathrm{~cd} / \mathrm{m}^{2}$ to lower than approximately $0,001 \mathrm{~cd} / \mathrm{m}^{2}$. This situation can cause tiredness of the human visual system. The personnel of the Central Railroad Yard often worked with dark adaptation, because the discrimination of wagons was impossible in some areas. Fig 3 shows a schematic illustration of the range of object luminances within which discrimination is possible for different adaptation luminances [3, 4].

People perceive objects, such as waggons, with the help of luminance differences between an object and background. The adaptation luminance has a marked influence on an observer's estimate of the visual range because, along with the visual angle of the object under observation, it determines the observer's threshold contrast. This effect of the adaptation luminance is to be distinguished from the influence of background luminance. In Fig 3 three points (points 1, 2 and 3) are presented as typical observable points of luminance in different areas in the railroad yard from the control tower. Point 1 presents the situation of a dark waggon in the

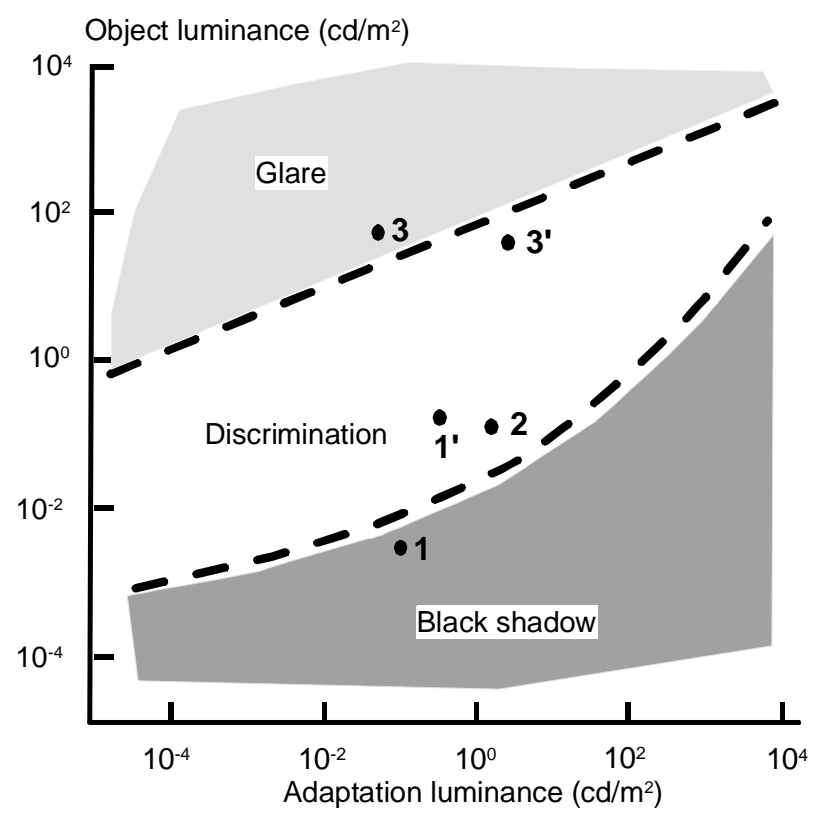

Fig 3. Dispersion of luminance in initial lighting situation (points 1,2 and 3) and after the rearrangement (points 1' and 3') adapted to the general layout in [3] and [4] 
classification yard, where lighting makes the signal-tonoise ratio between the waggon and its background too low. This point in a black shadow makes the visibility of the task poor and will be considered as inadequate for quality lighting. Point 2 presents the observable point in the hump area and point 3 for background lighting. The staff working in the control tower must continuously adjust the eye from "black shadow" to "glare" because the luminance gradient was big. In the area of a black shadow color can no longer be seen and details are impossible to be discriminated. The employees in the control tower complained about visual discomfort in the presence of bright light sources (highway lamps) at the back of the railroad yard. A high strain and rapid eye fatigue can be the results because of a low uniformity of luminance in the railfield.

On the basis of ergonomical investgation, it is ascertained that the initial lighting situation characterized by instability of illumination in the whole railroad yard causes visual discomfort and affects directly human performance. It impairs work motivation and the circadian system in a long run especially for the elder employees with a descending visual capability.

\section{Analysis of the stability and instability of ergo- nomic light improvement}

After the rearrangement of illumination the visual situation was significantly improved [1]. The new lighting concept has reached the aim to reduce the employees' visual strain and thus to increse the safety of night work. The new concept has provided a good-quality lighting that allows workers in the railroad yard to see what they need to see quickly and easily and does not cause any visual discomfort. It was noticed that different degrees of uniformity are desirable in different locations in the railroad yard. The most uniform illumination is required in the immediate working area such as hump area for the employees in the control tower. From the measurement results it was confirmed that visual discomfort was reduced through improvement of uniformity and stability of illumination. The main points of lighting improvement are listed as following:

- The measured values of medium horizontal illuminance were above the demanded DIN-value of $5 \mathrm{~lx}$ in every area.

- Sudden changes in illuminance levels in some areas were eliminated and the uniformities for the luminance were higher than $62 \%$ in all areas.

- Visual discomfort caused by waggon shadows was reduced.

- Visual acuity was improved by means of enhancement of luminance contrast.

The last point of the above improvements can be seen in figure 3 in comparison between points 1,3 and points 1', 3'. The measurement points 1 and 3 , which were placed in critical areas in the initial lighting situation, are replaced by points 1' and 3' (same measure- ment points like 1 and 3 ) after the rearrangement. The illuminance situation of both points are significantly improved and placed after the rearrangement in the "discrimination" area. This reduced visual fatigue and enhanced work motivation in the night shiftwork.

Four years after installation, the objective and subjective measurements showed that illuminance and maintenance were at a high level. The economic environment was favourable for transportation and the whole system of the railroad yard had a very high throughput at that time. The question is how the criteria for stability of the system can be described in a long-term scientific investigation.

After ten years, one of the important criteria for the stability of the project is seen in the maintenance of reduced strain and visual discomfort for the employees at different workplaces. The subjective judgements on the illumination and working activities operationalize the strain in the initial and rearranged situation. Table shows the results among workers under and over 50 years of age because of optical changes in the human visual system with increasing age.

Employees over 50 years should have severe problems according to literature [5, 6] with age-depending influence because of the static and the dynamic visual acuity as well as of the colour temperature preference. Energy was saved by realizing a high uniformity illuminance level and a high contrast, whereas the illuminance level was only raised to a limited extent. This leeds to a high positive judgement of a younger and even elder worker.

The difference of the judgements is not so notable among the workers under and over 50 years for carrying out the different tasks. The reason is seen in the enhanced experience of elder workers in different ac-

Comparison of subjective judgements

\begin{tabular}{|c|c|c|c|c|c|}
\hline \multirow{2}{*}{\multicolumn{2}{|c|}{ Characteristic $\quad$ Medium values about }} & \multicolumn{2}{|c|}{$\begin{array}{l}\text { Initial } \\
\text { situation }\end{array}$} & \multicolumn{2}{|c|}{$\begin{array}{l}\text { Rearranged } \\
\text { situation }\end{array}$} \\
\hline & & \multirow{2}{*}{\begin{tabular}{r|} 
over 50 \\
53,5
\end{tabular}} & \multirow{2}{*}{\begin{tabular}{|c|} 
under 50 \\
32,8 \\
\end{tabular}} & \multirow{2}{*}{$\begin{array}{l}\text { over } 50 \\
54,9\end{array}$} & \multirow{2}{*}{$\begin{array}{c}\text { under } 50 \\
37\end{array}$} \\
\hline Average of age & Years & & & & \\
\hline Belonging to company & Years & 15,5 & 8,9 & 23,1 & 9,8 \\
\hline Persons with glasses & $\%$ & 70,8 & 1,4 & 60 & 16 \\
\hline $\begin{array}{l}\text { The feeling of "unsafe" } \\
\text { because of the lack of } \\
\text { lighting }\end{array}$ & $\begin{array}{l}1 \text { low } \\
2 \text { medium } \\
3 \text { high }\end{array}$ & 2,42 & 2,16 & 1,71 & 1,03 \\
\hline Carrying out the work & $\begin{array}{l}1 \text { good } \\
2 \text { medium } \\
3 \text { bad }\end{array}$ & 2,78 & 2,54 & 1,21 & 1,27 \\
\hline Seeing the important thing & $\begin{array}{l}1 \text { good } \\
2 \text { medium } \\
3 \text { bad }\end{array}$ & 2,75 & 2,54 & 1,36 & 1,34 \\
\hline $\begin{array}{l}\text { Danger of accident in } \\
\text { the night work }\end{array}$ & $\begin{array}{l}1 \text { low } \\
2 \text { medium } \\
3 \text { high }\end{array}$ & 2,92 & 2,89 & 2,43 & 2,48 \\
\hline $\begin{array}{l}\text { Recognizing of flat } \\
\text { waggons }\end{array}$ & $\begin{array}{l}1 \text { good } \\
2 \text { medium } \\
3 \text { bad }\end{array}$ & 2,75 & 2,19 & 1,50 & 1,0 \\
\hline $\begin{array}{l}\text { Impairing of the visual } \\
\text { capability }\end{array}$ & $\begin{array}{l}1 \text { not at all } \\
2 \text { little } \\
3 \text { strong }\end{array}$ & 2,04 & 1,47 & 1,67 & 1,23 \\
\hline
\end{tabular}


tivities, which can compensate the lacking of illuminance by mental models. Elder workers state only little impairing for their visual capability over the years in this layout in contrast to literature.

\section{Discussion}

Nevertheless the final generalized survey after ten years shows that especially the uniformity of illuminance in all fields was going down again. Otherwise visual discomfort was increased. The reason was the replacement of old bulbs with significantly reduced lumen because of reducing operating costs in this railroad yard just before the generalized survey. It could be observed that the maintenance of lighting system is again at a low level with broken bulbs not replaced, aged lighting not substituted and dark ballast not displaced with a white or lightly coloured ballast. The working environment is affected by economic environment and the lighting situation could be characterized as instabile. The throughput of the system was significantly reduced and the number of persons working in the system is less than that of those working there before. The dynamic changes of the stability of the lighting system, throughput of waggons and maintenance situation are presented in Fig 4.

On the basis of the analysis the important effective factors for the stability and instability of an outdoor il-

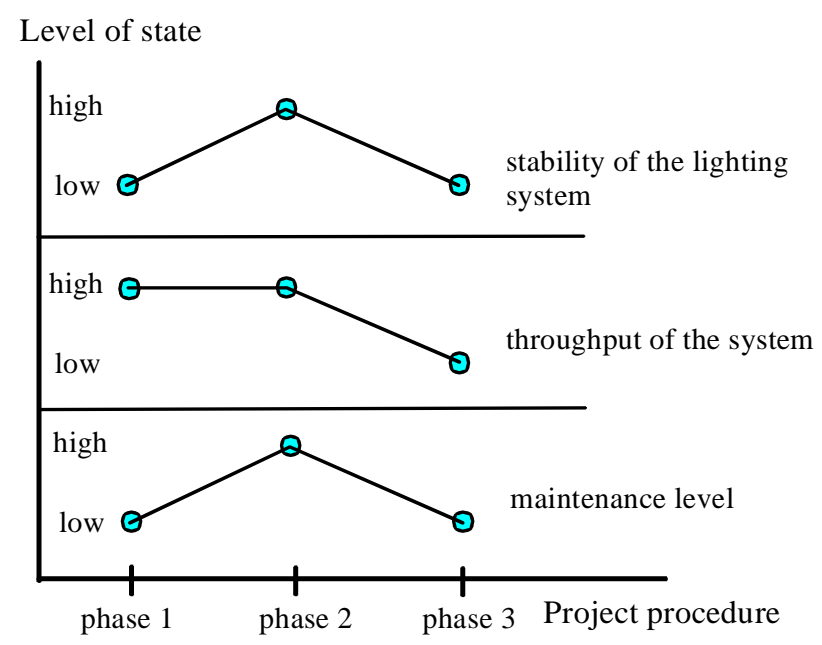

Fig 4. State of stability, throughput and maintenance in different project procedures

\begin{tabular}{|c|c|c|}
\hline reasons for instability & & $\begin{array}{l}\text { Support for working } \\
\text { environment: } \\
\text { high maintenance level } \\
\text { substitution of aged bulbs }\end{array}$ \\
\hline $\begin{array}{l}\text { Working environment: } \\
\text { low illuminance level } \\
\text { low uniformity } \\
\text { low contrast } \\
\text { strong glare }\end{array}$ & $\begin{array}{c}\text { System } \\
\text { Characteristic: } \\
\text { limited dynamic } \\
\text { system with }\end{array}$ & \begin{tabular}{|l} 
Working environment: \\
- high illuminance level \\
high uniformity \\
high contrast \\
low glare
\end{tabular} \\
\hline $\begin{array}{l}\text { Demotion of working } \\
\text { environment: } \\
\text { low maintenance level } \\
\text { aging of bulbs }\end{array}$ & little support & reasons for stability \\
\hline
\end{tabular}

Fig 5. Effective stability factors lumination installation are summarized in Fig 5.

Fig 5 shows the reasons for stability and instability, if the lighting system is characterized as a limited dynamic system with little support. The following interaction of the factors for stability and instability can be assumed: a low illuminance level combined with a low uniformity and/or a low contrast and/or a strong glare leads to a deterioration of the system. This is because people working in the system cannot discriminate the additional deterioration caused by a low maintenance level. This situation can impair work efficiency and accidents might happen especially for workers over 50 years. On the other hand, when the illuminance level and uniformity as well as contrast are high and glare is low, the discrimination of unsatisfactory maintenance can be easily realized, and there is a push towards a higher maintenance level and substitution of aged bulbs by the workers. As a result, the visual stress will be reduced and the safety will be improved.

\section{Conclusions}

A good stability is important for industrial productivity as well as for human performance, visual comfort and safety. On the basis of the investigation the following conclusions can be drawn:

- The stability of an ergonomic layout is limited and affected mostly by an economic environment.

- The duration of the stability of an ergonomic layout is shorter than the duration of the technical layout.

- The stability of an ergonomic layout can be selfintensifying via improvement of human performance and reduced visual discomfort.

- Instability can be easily installed when the layout of the system is on the edge of human ability.

Taking this into consideration effective and energy saving outdoor layouts can be realized freeing the workers and the management from the fear of accidents.

\section{References}

1. Fröhner, K.-D.; Li, Z. Reliable design of illumination in railroad yards. Environmental Engineering (Aplinkos inžinerija), No 1(5), 1996, p 5-10.

2. Fröhner, K.-D.; Li, Z. Evaluating improved illumination of railroad yards. Environmental Engineering (Aplinkos inžinerija), Vol VI, No 2, 1998, p 48-52.

3. Boyce, P. R. Human Factors in Lighting. Taylor \& Francis, 2003, ISBN 0-7484-0950-5

4. Hopkinson, R. G. and Collins, J. B. The Ergonomics of Lighting. London: McDonald \& Co. Ltd, 1970.

5. Owsley C.; Sekuler, R.; Siemsen, D. Contrast sensitivity throughout adulthood. Vision Res., Vol 23, No 7, 1983, p 689-699.

6. Ehrenstein, W. H.; Wist, E. R.; Cavonius, C. R. Visual Acuity Based on Motion Contrast: Evaluation with Professional Drives. Advances in Occupational Ergonomics and Safety I, Vol 2, 1996, p 215-220. 


\section{LAUKO APŠVIETIMO IRANGOS STABILUMAS IR NESTABILUMAS}

\section{K.-D. Fröhner, Z. Li}

\section{$\mathrm{S}$ a $\mathrm{n} \mathrm{t} \mathrm{r} \mathrm{a} \mathrm{u} \mathrm{k} \mathrm{a}$}

Projektuojamo lauko apšvietimo ịrangos stabilumas ar nestabilumas turi itakos darbuotojų darbo saugumui ir sveikatai. Siekiant, kad darbo sąlygos būtų palankesnès, dešimtị pastaruju metų projektuojant lauko apšvietimą buvo atliekami tyrimai.

Dirbant kintamomis sąlygomis apšvietimas ne tik gali sukelti darbuotojams regejjimo diskomforta, bet ir turi tiesioginès itakos jų darbui. Straipsnyje analizuojama, kaip darbuotojai prisitaiko prie lauko apšvietimo, ir kokios itakos jis turi jų darbo kokybei. Tokių tyrimų tikslas - tobulinti apšvietimą, kad sumažètų nelaimingų atsitikimų naktinèse pamainose, didètų darbo efektyvumas.

Raktažodžiai: stabilumas, apšvietimas, skaistis, regėjimo diskomfortas, žmonių darbas, geležinkelio manevravimo stotis.

\section{СТАБИЛЬНОСТЬ И НЕПОСТОЯНСТВО НАРУЖНОГО ОСВЕЩЕНИЯ ПРОЕКТИРУЕМЫХ РАБОЧИХ МЕСТ}

к.-Д. Френер, 3. Ли

$\mathrm{P}$ е 3 ю $\mathrm{M}$ e

Стабильность и непостоянство наружного освещения проектируемых рабочих мест оказывают воздействие на безопасность работы и здоровье работников. Работая над улучшением условий труда и проектируя наружное освещение, авторы в течение последних десяти лет исследовали влияние наружного освещения. В динамических условиях исследуемое освещение оказывает непосредственное воздействие на визуальный дискомфорт работников и их работу. Проанализирована адаптация работников к наружному освещению и ее влияние на качество работы. Исследование проблемы должно способствовать уменьшению числа несчастных случаев в ночную смену, а также улучшению эффективности работы.

Ключевые слова: стабильность, освещение, освещенность, визуальный дискомфорт, работа людей, железнодорожные маневренные пути. 